\title{
Spatial and temporal variations of meiofaunal communities from the western sector of the Gulf of Batabanó, Cuba: III. Vertical distribution
}

\author{
M. Armenteros ${ }^{1 *}$, J. P. Williams ${ }^{2}$, B. Creagh ${ }^{1} \&$ N. Capetillo ${ }^{3}$ \\ 1. Centro de Investigaciones Marinas, Universidad de La Habana. 16 \# 114, Playa, CP 11300, Ciudad Habana, Cuba. \\ maickel@cim.uh.cu \\ 2. 1700 Sylvia Flores Street, Dangriga Town, Stann Creek District, Belize. jaypwill@gmail.com \\ 3. Centro de Investigaciones Pesqueras, Ministerio de La Industria Pesquera. Playa, CP 11500, Ciudad Habana, Cuba. \\ norberto@cip.telemar.cu \\ * Corresponding author
}

Received 03-VII-2007. C Corrected 30-VI-2008. Accepted 31-VII-2008.

\begin{abstract}
The vertical distribution of meiofauna within subtidal sediments was studied in four stations pertaining to mangrove or muddy flats habitats. In 2003, replicated samples were taken in dry (February) and wet (July) seasons at the Bacunagua Inlet, southwestern coast of Cuba. The abundance and number of meiofaunal taxa exhibited a vertical gradient possibly due to changes in the concentrations of oxygen and hydrogen sulphide, rather than food availability along this gradient. Nematodes are capable of distributing themselves throughout the whole sediment column due to their ability to tolerate reducing conditions; however depletion of communities along depth was evident. Their presence in deeper sediments $(6-10 \mathrm{~cm})$ suggests that certain species are adequately adapted to spend their entire life cycle in these harsh environments (where soluble tannins and decomposing organic matter predominate). Copepods showed a strong limitation to vertical distribution (concentrating in the top $2 \mathrm{~cm}$ ), possibly in response to a sharp vertical decline in oxygenation within these organically enriched sediments. Rev. Biol. Trop. 56 (3): 1127-1134. Epub 2008 September 30.
\end{abstract}

Key words: meiofauna, vertical distribution, Caribbean Sea, mangroves, muddy flats.

The communities of meiofauna from soft bottom habitats show notable patchiness in their temporal and spatial distribution (Hodda 1990, Soetaert et al. 1995). In comparison to other benthic assemblages (e.g. macrofauna, macroalgae, stony corals, sponges), meiofauna have a well defined three dimensional distribution based on adaptations of their species to occupy the spaces within sediments up to several centimetres in depth (Soetaert et al. 1994). The vertical distribution depends on particular ecological processes (e.g. oxygenation of pore water, interstitial circulation, concentration of $\mathrm{H}_{2} \mathrm{~S}$ ), still poorly understood (Steyaert et al. 1999). In comparison to temperate habitats, the ecology of meiofauna in tropical areas still needs to be widely explored, particularly the vertical distribution.
Mangroves are subtidal or intertidal tropical ecosystems characterized by high primary production and where the presence of vascular plants affects notably the associated assemblages of fauna. Research on meiofauna in mangrove ecosystems has been carried out in several places around the world, and insights on the effects of mangrove litter (Alongi 1987), disturbance by macrofauna (Olafsson and Ndaro 1997), spatial distribution (Hodda 1990, Armenteros et al. 2006) and seasonality (Hodda and Nicholas 1986) exist. The vertical distribution of meiofauna within tropical mangrove sediments and the factors that affect it are poorly studied; only two surveys (Ansari et al. 1980, Somerfield et al. 1998) have been published concerning this topic. 
Muddy flats are common habitats in shallow waters, particularly in semi/close estuaries (e.g. bays and coastal lagoons) or in the mouth of rivers and creeks. In tropical muddy flats, meiofaunal surveys concerning spatial and temporal distribution (Dittman 2000), effects of physical disturbance (Aller and Aller 2004), and effects of pollution (Warwick et al. 1990, Ólafsson et al. 1995) have been identified. Information on vertical distribution of meiofauna in these temperate habitats is relatively abundant (e.g. Joint et al. 1982, Jensen 1987, Moodley et al. 2000); however, in tropical areas it is scarce, and very few papers (e.g. Boucher and Gourbault 1990, Aller and Stupakoff 1996) have been published.

This paper is our third contribution on temporal and spatial variation of the meiofauna community structure in the Gulf of Batabanó, Cuba. The objective is to describe the vertical distribution of meiofauna in two different habitats and to search for differences between weather seasons and stratum depth.

\section{MATERIALS AND METHODS}

Study zone. Samples were taken in mangroves and muddy flats from the Bacunagua inlet in the western sector of the Gulf of Batabanó, Cuba in February and July, 2003. Mangrove forests have three species: Rhizophora mangle, Avicennia germinans and Laguncularia racemosa (in the direction sea to land). The tidal amplitude in the area was narrow $(25 \mathrm{~cm}$ after Rodriguez and Rodriguez 1983). Muddy flats were extensive areas of sandy-muddy sediment with some interspaced patches of seagrass (Thalassia testudinum). The bottoms were soft and the average percent of silt + clay for both habitats was $56 \%$ (range: $29-82 \%$ ).

Sampling design. Sampling was done in two weather seasons; February (dry season) and July (wet). Two sampling stations $\left(22^{\circ} 29^{\prime} 33^{\prime \prime} \mathrm{N}, 83^{\circ} 04^{\prime} 56^{\prime \prime} \mathrm{W}\right.$ and $22^{\circ} 29^{\prime} 33^{\prime \prime} \mathrm{N}$, $83^{\circ} 04^{\prime} 22^{\prime \prime} \mathrm{W}$ ) were located in mangrove forests. Three sampling units (SU) were taken in each station, in the subtidal sediment among prop roots of $R$. mangle. Two sampling stations $\left(22^{\circ} 28^{\prime} 19^{\prime \prime} \mathrm{N}, 83^{\circ} 04^{\prime} 00^{\prime \prime} \mathrm{W}\right.$ and $22^{\circ} 28^{\prime} 38^{\prime \prime}$ $\mathrm{N}, 83^{\circ} 04^{\prime} 00^{\prime \prime} \mathrm{W}$ ) were located in the muddy flat areas. Three SU were taken in each station in patches of subtidal bare sediment. The SU consisted of a plastic corer (50 mL syringe) having an area of $5.3 \mathrm{~cm}^{2}$. The corer was vertically buried into the sediment to a depth of 10 $\mathrm{cm}$. The extracted column from each corer was immediately separated with a plunger into four strata $(0-2,2-4,4-6$ and 6-10 cm). Temperature, salinity, dissolved oxygen (DO), $\mathrm{pH}$ and depth were recorded at bottom water with an oceanographic probe (Hydrolab 4a).

Sample processing. Each sample (= stratum) was keep in a nylon bag with $10 \%$ buffered formalin. In the laboratory, samples were sieved through 500 and $45 \mu \mathrm{m}$ nylon test sieves with filtered tap water. Material retained in the later sieve was kept for meiofaunal extraction. The animals were sorted from the sediment using a high density solution (commercial sugar crystals plus tap water to a density of $1.18 \mathrm{~g} \mathrm{~cm}^{-3}$ ) and manual agitation in a container. The mixture solution, including the sediment, was allowed to settle for $20 \mathrm{~min}$ and the supernatant (i.e. solution plus sorted animals) was decanted unto the $45 \mu \mathrm{m}$ sieve. This procedure was repeated three times. The meiofauna were enumerated and identified to major taxa (i.e. nematodes and copepods) under a stereomicroscope (maximum 56X).

Data analysis. Data of animal density and number of taxa were analyzed separately for each habitat and for each month in order to detect differences among stratum $(0-2,2-4$, 4-6 and 6-10 cm). Two-way analyses of variance (stratum $x$ month) were not calculated because the assumptions for the parametric statistic were not fulfilled. Consequently, an one-way non-parametric analysis of variance (Kruskal - Wallis) was carried out on the univariate measures of community (total density of meiofauna and percentage of nematodes) for each month. Two-way analyses of similarity (ANOSIM after Clarke and Warwick 2001) 
were done on multivariate structure of community with data transformed as square root. Multidimensional scaling (MDS) ordination plots were built on the similarity matrix (using the same similarity matrix that in ANOSIM) in order to graphically represent the relationship among the samples on the basis of multivariate community structure.

\section{RESULTS}

Abiotic factors. Seasonal changes in water bottom temperature, salinity, DO and $\mathrm{pH}$ were noted (Table 1). In February (dry season), values of temperature, $\mathrm{DO}$ and $\mathrm{pH}$ were lower than in July (wet season) whereas, the salinity was higher in February. Between the two habitats, smaller differences appear to exist in the same month regarding temperature, DO and $\mathrm{pH}$. Depth was notably different between habitats, with higher values in muddy flats.

Mangroves. Four major meiofaunal taxa were recorded in mangrove sediments: Nematoda, Copepoda, Ostracoda and Acari. On February, there are significant differences in total density of meiofauna among vertical strata $(\mathrm{H}=9.6 ; \mathrm{p}=0.02 ; \mathrm{N}=22)$; however, none could be detected on July $(\mathrm{H}=4.79$; $\mathrm{p}$ $=0.19 ; \mathrm{N}=24)$. Figure 1 suggests that the differences on February were a result of high numbers of meiofaunal organisms in the top layer of sediment. The highest density of nonnematode meiofauna occurs in the top layer $\left(3.6 \pm 6.0\right.$ animals $\left.10 \mathrm{~cm}^{-2}\right)$ in comparison with deeper strata $\left(<0.8\right.$ animals $\left.10 \mathrm{~cm}^{-2}\right)$. As a consequence, the mean percentage of nematodes $( \pm \mathrm{SD})$ in the top layer is smaller $(79.7 \pm$ $21.8 \%)$ than in the remaining strata $(>96 \%$ in any stratum).

A multivariate two-way ANOSIM test did not show statistical differences among strata $(\mathrm{R}$ $=0.09 ; \mathrm{p}=0.14 ; 999$ permutations) or between months $(\mathrm{R}=0.1 ; \mathrm{p}=0.17 ; 999$ perm. $)$. A MDS plot did not reveal any clear pattern of sample grouping (fig. 2); the superposition of samples in the plot was due to several samples with only nematodes and very similar densities ( 1 or 2 animals $10 \mathrm{~cm}^{-2}$ ).

Muddy flats. Five meiofaunal taxa were detected in the sampling: Nematoda, Copepoda, Polychaeta, Ostracoda and Tanaidacea. There are significant differences in total density of meiofauna on February $(\mathrm{H}=11.3 ; \mathrm{p}=0.01$; $\mathrm{N}=18)$ and on July $(\mathrm{H}=10.7 ; \mathrm{p}=0.01 ; \mathrm{N}=$ 22). Figure 1 shows a vertical distribution of meiofauna characterized by gradual decrease in density from surface to the deepest layers of sediment. Both months showed a higher density of animals in the top two centimetres, fundamentally nematodes $(94.7 \pm 5.1 \%)$; again the highest density of non-nematode fauna $(3.0 \pm$ 3.2 animals $10 \mathrm{~cm}^{-2}$ ) was in the surface layer of sediment. A two-way ANOSIM test showed differences among strata $(\mathrm{R}=0.27 ; \mathrm{p}=0.002 ; 999$ perm.); but did not detect differences between months $(\mathrm{R}=-0.003 ; \mathrm{p}=0.46 ; 999$ perm.). A MDS ordination plot (fig. 3) did not reveal any clear patterns of sample grouping except a wider dispersion of samples from the deepest stratum $(6-10 \mathrm{~cm})$ in comparison to other strata.

TABLE 1

Mean values (standard deviation) of abiotic factors in mangrove and muddy flat habitats from the Bacunagua Inlet, Gulf of Batabanó, Cuba. Number of observations = two for each mean. $T=$ temperature, $D O=$ dissolved oxygen

\begin{tabular}{llccccc} 
Habitat & Month & Depth $(\mathrm{m})$ & $\mathrm{T}\left({ }^{\circ} \mathrm{C}\right)$ & Salinity $(\%)$ & DO $\left(\mathrm{mg}^{-1}\right)$ & $\mathrm{pH}$ \\
Mangrove & February & $0.5(0.1)$ & $29.3(0.2)$ & $33.8(1.1)$ & $5.33(0.28)$ & $7.77(0.01)$ \\
& July & $0.6(0.1)$ & $32.6(0.5)$ & $27.3(1.9)$ & $5.46(0.49)$ & $8.48(0.00)$ \\
\multirow{3}{*}{ Muddy flat } & February & $2.8(0.1)$ & $28.3(0.5)$ & $35.6(0.0)$ & $6.73(0.26)$ & $8.08(0.08)$ \\
& July & $3.1(0.2)$ & $31.3(0.1)$ & $31.5(0.1)$ & $7.91(0.05)$ & $8.74(0.00)$
\end{tabular}




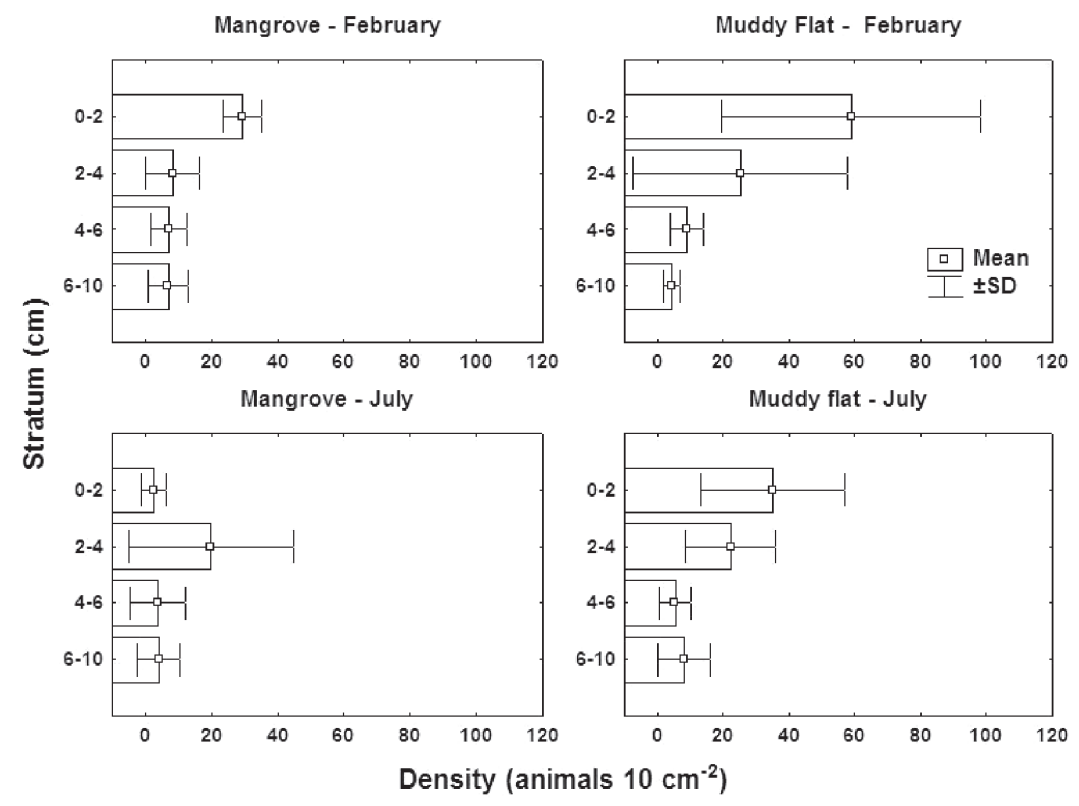

Fig. 1. Mean values and standard deviations (SD) of meiofaunal density distributed by strata within sediments from mangroves and muddy flats in the Gulf of Batabanó, Cuba.

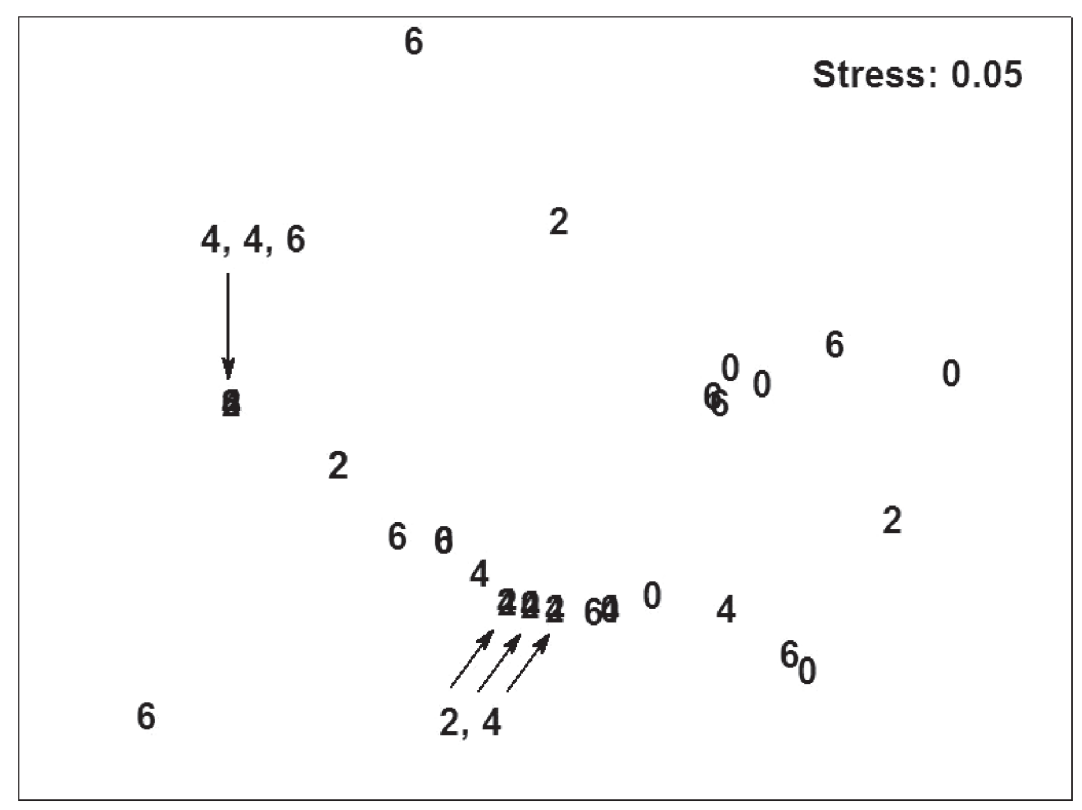

Fig. 2. Multidimensional scaling plot of samples of meiofauna from mangrove habitats. Samples were separated in strata of depth within sediment. The labels in the plot: $0=0-2 \mathrm{~cm}, 2=2-4 \mathrm{~cm}, 4=4-6 \mathrm{~cm}$ and $6=6-10 \mathrm{~cm}$. Some superposed samples in the plot are indicated by labels + arrows. 


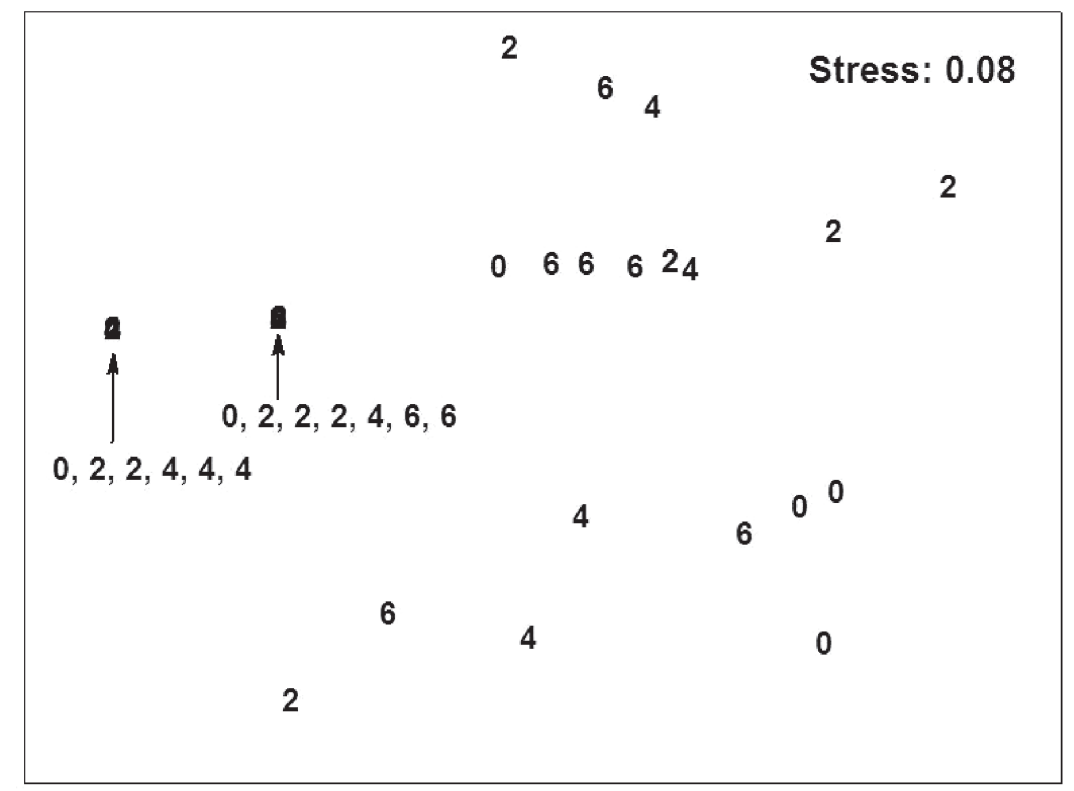

Fig. 3. Multidimensional scaling plot of samples of meiofauna from muddy flat habitats. Samples were separated in strata of depth within sediment. The labels in the plot: $0=0-2 \mathrm{~cm}, 2=2-4 \mathrm{~cm}, 4=4-6 \mathrm{~cm}$ and $6=6-10 \mathrm{~cm}$. Some superposed samples in the plot are indicated by labels + arrows.

\section{DISCUSSION}

The vertical distribution of meiofauna did not show clear seasonal differences in both habitats. We suggest two non-exclusive causes: (i) the seasonal changes in measured variables in our study were slight (salinity: $<6 \%$; dissolved oxygen: $<1.5 \mathrm{mg} \mathrm{l}^{-1}$ ); therefore they did not cause temporal variability in the vertical gradient of fauna. At least for the salinity, its change at mangroves (e.g. a difference of $23 \%$ between dry and wet season) in the same region appears to be more important for meiofauna than absolute value (Armenteros et al. 2006). And (ii) the dynamic properties at the water - sediment boundary layer that affect of meiofauna (e.g. flow regime and transport of sediment after Snelgrove and Butman 1994) do not show differences between sampled months; unfortunately we could not measure the mentioned processes.

The vertical profiles obtained in this survey were in accordance with most of the other surveys concerning vertical distribution of meiofauna; i.e. differential distribution of meiofauna across the sediment column. The bulk of the meiofauna appears in the uppermost centimetre, possibly caused by (i) strong vertical gradient in chemical and physical properties of sediment and/or (ii) higher food availability in surface layer.

We accredited the vertical gradient in the distribution of meiofauna to first mentioned cause; i.e. the concomitant decreasing of oxygen and increase of hydrogen sulphide $\left(\mathrm{H}_{2} \mathrm{~S}\right)$ into the deep in sediments. Particularly in fine sediments, the penetration of oxygen is limited to a few millimetres, below this first oxygenated layer the concentration of $\left(\mathrm{H}_{2} \mathrm{~S}\right)$ increases causing deleterious effects on fauna (Dye 1983). The presence of $\mathrm{H}_{2} \mathrm{~S}$ in the sediment from Bacunagua was evident due to a presence of black mud and also by the strong smell that we could detect during sampling.

The another possible reason explains vertical gradient of meiofauna would be that quantity of organic matter, algae and bacteria tend to be 
higher in the surface layer (Reise and Ax 1979, Joint et al. 1982) and it suffers a noted decline with depth (Reise and Ax 1979). However, we suspect that food availability in surficial sediments is not a major factor ruling the vertical distribution since sandy areas adjacent to our study site showed poor organic content (possibly correlated to food availability) but the concentration of meiofauna in the top layer $(0-2$ $\mathrm{cm}$ ) is less notable. Also, in these sandy sites a deeper penetration of fauna within sediment was evident (M. Armenteros, unpublished). The concentration of fauna in the top $2 \mathrm{~cm}$ and a lesser penetration within muddy sediments, in comparison to sandy bottoms (see Ansari et al. 1980, Boucher and Gourbault 1990), supports the key role of chemical - physical properties of interstitial water on meiofauna.

The vertical distribution of meiofauna is mainly maintained by nematodes, because other meiofauna practically was absent below 2 $\mathrm{cm}$ deep. The nematode assemblage is capable of distribution throughout the whole column of sediment (Hodda and Nicholas 1985, Nicholas et al. 1991, Somerfield et al. 1998, Zhou 2001). They are more tolerant to reducing conditions inside the sediment and capable of spending their whole life cycle in the presence of hydrogen sulphide (Heip et al. 1985). However, Reise and Ax (1979) rejected the idea that meiofauna can live entirely by anaerobic respiration, suggesting that they are merely able to tolerate anaerobic intervals. The presence of nematodes in the deep layer $(6-10 \mathrm{~cm})$ suggests that certain species are adapted to inhabit these areas during long periods and not merely vertical migrants. The deeper layer should be less attractive for nematode migration due to high quantities of buried decomposing mangrove leaves (personal observation) causing an adverse environment for the meiofauna by: (i) depleting oxygen concentrations and producing $\mathrm{H}_{2} \mathrm{~S}$ (Dye 1983, Somerfield et al. 1998, Zhou 2001); and (ii) accumulating soluble tannins (Alongi 1987). An increase in the relative variability of community structure (e.g. measured as dispersion in a MDS plot) is a symptom of environmental stress (Lambshead and Hodda
1994); therefore, the higher variability in the deeper layer, detected in present study, is an additional support for the existence of more adverse conditions.

A restriction in the vertical distribution was evident in this study, where copepods appeared only in the 0-2 stratum depth. Very few individuals were in the deeper layers and a more probable reason for their presence would be that they migrated there while still in the corer before it was split in strata. Copepods are especially sensitive to oxygen depletion in sediment (Hicks and Coull 1983), and for this reason they are confined to the upper centimetre in tropical (Somerfield et al. 1998, Zhou 2001) and temperate (Hodda and Nicholas 1985) mangrove habitats. In temperate muddy flats, copepods are limited to the upper $2 \mathrm{~cm}$ (Joint et al. 1982, Fleeger et al. 1995). Only in sandy, well sorted sediment, are copepods capable of living below $4 \mathrm{~cm}$ of depth (Boucher and Gourbault 1990).

In summary, a vertical gradient of abundance and number of meiofauna taxa was noted, which probably reflected vertical changes in the chemical environment other than food availability in sediment surface. Nematodes exhibited a wider distribution throughout the sediment while copepods were more restricted to the surface; possibly related to oxygen concentrations. Nematode assemblages spending their whole life cycle in deeper layers appears to occur in mangrove sediments.

\section{ACKNOWLEDGEMENTS}

This research was supported by the Ministry of Fisheries of the Republic of Cuba. We especially thank the crew of V/R Cayo Largo 26 for their help during field sampling.

\section{RESUMEN}

Se estudió la distribución vertical de la meiofauna dentro de los sedimentos en cuatro estaciones ubicadas en manglares y planos fangosos. En el año 2003, tomamos muestras (con repetición) en época de seca (febrero) y de lluvia (julio) en la ensenada de Bacunagua, costa 
suroccidental de Cuba. La abundancia y el número de táxones de la meiofauna mostraron un gradiente vertical debido posiblemente a cambios en las concentraciones de oxígeno y sulfuro de hidrógeno, más que a la disponibilidad de alimento a lo largo del gradiente. Los nemátodos son capaces de distribuirse a través de la columna de sedimento debido a su habilidad para tolerar condiciones reducidas; sin embargo, fue evidente la reducción de las comunidades con la profundidad. Su presencia en los sedimentos profundos (6-10 cm) sugiere que ciertas especies están adecuadamente adaptadas a permanecer todo su ciclo de vida en un ambiente adverso (donde predominan los taninos solubles y la descomposición de la materia orgánica). Los copépodos mostraron una fuerte limitación en su distribución vertical (concentrándose en los $2 \mathrm{~cm}$ superficiales) posiblemente como respuesta a un gradiente marcado en la oxigenación dentro de estos sedimentos enriquecidos orgánicamente.

Palabras clave: meiofauna, distribución vertical, Mar Caribe, manglares, planos fangosos.

\section{REFERENCES}

Aller, J.Y. \& R.C. Aller. 2004. Physical disturbance creates bacterial dominance of benthic biological communities in tropical deltaic environments of the Gulf of Papua. Contin. Shelf Res. 24: 2395-2416.

Aller, J.Y. \& I. Stupakoff. 1996. The distribution and seasonal characteristics of benthic communities on the Amazon shelf as indicators of physical processes. Contin. Shelf Res. 16: 717-751.

Alongi, D.M. 1987. The influence of mangrove-derived tannins on intertidal meiobenthos in tropical estuaries. Oecologia 71: 537-540.

Ansari, Z.A., A.H. Parulekar \& T.G. Jagtap. 1980. Distribution of sub-littoral meiobenthos off Goa coast, India. Hydrobiologia 74: 209-214.

Armenteros, M., I. Martín, J.P. Williams, B. Creagh, G. González-Sansón \& N. Capetillo. 2006. Spatial and temporal variations of meiofaunal communities from the western sector of the Gulf of Batabanó , Cuba. I. Mangrove systems. Estuaries Coasts 29: 124-132.

Dittmann, S. 2000. Zonation of benthic communities in a tropical tidal flat of north-east Australia. J. Sea Res. 43: 33-51.
Fleeger, J.W., T.C. Shirley \& J.N. McCall. 1995. Fine-scale vertical profiles of meiofauna in muddy subtidal sediments. Can. J. Zool. 73: 1453-1460.

Hodda, M. 1990. Variation in estuarine littoral nematode populations over three spatial scales. Estuar. Coast. Shelf Sci. 30:325-340.

Hodda, M. \& W.L. Nicholas. 1986. Temporal changes in littoral meiofauna from the Hunter River estuary. Aust. J. Mar. Fresh. Res. 37: 729-741.

Jensen, P. 1987. Differences in microhabitat, abundance, biomass and body size between oxybiotic and thiobiotic free-living marine nematodes. Oecologia 71: 564-567

Joint, I.R., J.M. Gee \& R.M. Warwick. 1982. Determination of fine-scale vertical distribution of microbes and meiofauna in an intertidal sediment. Mar. Biol. 72: 157-164.

Moodley, L., G. Chen, C. Heip \& M. Vincx. 2000. Vertical distribution of meiofauna in sediments from contrasting sites in the Adriatic Sea: Clues to the role of abiotic versus biotic control. Ophelia 53: 203-212.

Nicholas, W.L., J.A. Elek, A.C. Stewart \& T.G. Marples. 1991. The nematode fauna of a temperate Australian mangrove mudflat; its population density, diversity and distribution. Hydrobiologia 209: 13-27.

Ólafsson, E., R.W. Johnstone \& S.G.M. Ndaro. 1995. Effects of intensive seaweed farming on the meiobenthos in a tropical lagoon. J. Exp. Mar. Biol. Ecol. 191: 101-117.

Ólafsson, E. \& S.G.M. Ndaro. 1997. Impact of the mangrove crabs Uca annulipes and Dotilla fenestrata on meiobenthos. Mar. Ecol. Progr. Ser. 158: 225-231.

Reise, K. \& P. Ax. 1979. A meiofaunal "thiobios" limited to the anaerobic sulfide system of marine sand does not exist. Mar. Biol. 54: 225-237.

Snelgrove, P.V.R. \& C.A. Butman. 1994. Animal-sediment relationships revisited: cause versus effects. Oceanogr. Mar. Biol. Annu. Rev. 32: 111-177.

Somerfield, P.J., J.M. Gee \& C. Aryuthaka. 1998. Meiofaunal communities in a Malaysian mangrove forest. J. Mar. Biol. Assoc. U. K. 78: 717-732. 
Steyaert, M., N. Garner, D. van Gansbeke \& M. Vincx. 1999. Nematode communities from the North Sea: environmental controls on species diversity and vertical distribution within the sediment. J. Mar. Biol. Assoc. U.K. 79: 253-264.

Soetaert K., M. Vincx, J. Wittoeck \& M. Tulkens. 1995. Meiobenthic distribution and nematode community structure in five European estuaries. Hydrobiologia 311: 185-206.
Warwick R.M., H.M. Platt, K.R. Clarke, J. Agard \& J. Gobin. 1990. Analysis of macrobenthic and meiobenthic community structure in relation to pollution and disturbance in Hamilton Harbour, Bermuda. J. Exp. Mar. Biol. Ecol. 138: 119-142.

Zhou, H. 2001. Effects of leaf litter addition on meiofaunal colonization of azoic sediments in a subtropical mangrove in Hong-Kong. J. Exp. Mar. Biol. Ecol. 256: $99-121$. 